\title{
Impact of Debt Threshold Level on GDP Per Capita Growth: Evidence of G7 Advance Countries
}

\author{
Irfan Alam \\ Department of Management Sciences, Ghulam Ishaq Khan Institute of Engineering Sciences and Technology, Topi, Pakistan \\ Email address: \\ irfan.alam@giki.edu.pk \\ To cite this article: \\ Irfan Alam. Impact of Debt Threshold level On GDP Per Capita Growth: Evidence of G7 Advance Countries. International Journal of \\ Science, Technology and Society. Vol. 7, No. 5, 2019, pp. 74-77. doi: 10.11648/j.ijsts.20190705.11
}

Received: April 18, 2019; Accepted: July 27, 2019; Published: November 25, 2019

\begin{abstract}
The aim of this study is to investigate the relationship between debt threshold and GDP per capita growth by using Panel Threshold Regression. The sample of the study is G7 (Advanced Countries) from the period of 1995 to 2015. The results suggested that the scale of debt threshold is ambiguous in this study because debt threshold has not significant effect on GDP per capita growth at the threshold level of $62.47 \%$. The magnitude of debt effect is not same on below and above threshold level. If debt is below and above from $62.47 \%$, its significant positive effect on GDP growth at $0.70 \%$ and $0.47 \%$ respectively. Also, explanatory variables are used in the study include inflation, trade to GDP, gross saving to GNI, government final consumption expenditure and total investment to GDP. There is a mix result of explanatory variables in the study as inflation and trade to GDP have positive effect on GDP per capita growth but does not produce significant result while gross saving and total investment to GDP have significant positive effect on GDP growth. At last, government final consumption expenditure has significant negative effect on GDP growth.
\end{abstract}

Keywords: GDP Per Capita Growth, Public Debt, Threshold Effect, Panel Threshold Regression, G7 (Advance Countries)

\section{Introduction}

Many empirical studies conducted in the past showing the public debt is growth-enhancing tools by many countries mostly for developed and developing countries. But the relationship between debt and GDP growth are far from conclusive. Some empirical studies show significant positive relationship while other studies suggested negative relationship. On the other hand, few studies highlighted that there is no significant relationship between it. So far, it is great interest to analyze the relationship between the accumulation of debt and GDP growth of G7 countries.

It is widely accepted that public debt is worldwide phenomenon for both developed and developing countries and most of the countries across world borrow funds for their development, budget deficits or both [1-3]. In the era of 2007 to 2009 , financial crisis emerged causes increase in debt and deficit ratios lead to fiscal and financial instability of many advance countries. It slow down the growth rate of many advances countries and arise the questions that government should take debt at a certain level because huge debt accumulation ultimately leads to negative effect on economic growth at the end.

Despite the important of this study, there are few studies conducted on developed countries specially G7 (Advance countries) examines the relationship between public debt and GDP growth. Precisely the motivation of this study is to investigate debt threshold level and it effect on GDP growth of G7 countries by using the annual data from 1995 to 2015 . In the study, our estimation model includes some explanatory variables that expected to influences on GDP growth.

\section{Review of Literature}

The empirical studies on the relationship between debt and GDP growth has widely been discussed in literature. But most of the studies emphasize the impact of debt on growth enhancing for developing countries and in particularly, determine the debt threshold level is scarce. The study across advance countries are virtually absent. For yet, such analyses conduct on advance countries are more relevant because the absorption in that economies is larger than other countries. Several studies conducted on advance countries focuses on the impact of debt and growth level. 
The theoretical literature mostly suggested that the public debt has negative impact on GDP growth but many studies found negative but insignificant result between the variables. The author find no significant relationship between public debt and GDP growth of 44 industrial countries $[1,4]$ while another vast study uses a sample of 44 countries over the period of 200 years [5]. The study found positive effect on growth on the low level of public debt and negative effect on growth on the high level of public debt.

Follow by these studies, the study could not found significant result on growth even the high debt level [5-6] While, find inverse relationship between the variables $[7,2]$. The another study analyzed the relationship between debt and GDP growth of 118 of advance, emerging and developing countries. The study found no threshold level over the period of all countries [8, 3].

To sum the literature, there is no consensus related to the effect of debt to GDP on GDP growth. On this point, the study adopts conventional approach that in the short run, public debt has positive effect on income, aggregate demand and total output $[9,4]$ while in the long run, large public debt causes (crowd out) decrease in private investment and increase in interest rate and harm growth of the economics $[10,5]$.

\section{Research Methodology}

\subsection{Data and Estimation}

The study consists the balanced panel data of G7 countries during the period of 1995 to 2015 by using estimation of threshold by likelihood ratio test [11]. Data are collected from World Bank and IMF database.

\subsection{Population and Sample}

The study consists G7 advance countries. Subject to the data availability, public debt to GDP and GDP per capita growth along with explanatory variables are used over the period of 1995 to 2015 .

Table 1. Countries in the Sample.

\begin{tabular}{lll}
\hline United States of America & Italy & Canada \\
\hline Japan & Germany & United Kingdom \\
France & L & . \\
\hline
\end{tabular}

\subsection{Summary of the Variables}

Table 2. Variables Summary.

\begin{tabular}{ll}
\hline Variables & Sources \\
\hline GDP per capita Growth (annual \%) & World Development Indicators \\
Public Debt to GDP & IMF Historical Public Debt \\
Inflation & World Development Indicators \\
Trade (\%) of GDP & World Development Indicators \\
Gross saving (\% of GDP) & World Development Indicators \\
General Government Final Consumption Expenditure (\% of GDP) & World Development Indicators \\
Total Investment (\% of GDP) & IMF Database \\
\hline
\end{tabular}

\subsection{Panel Threshold Regression Model}

Panel threshold regression model are attractive among other regression model as they allow for regression of splitting the observations with threshold values. The author proposed a threshold method for estimation of threshold level by likelihood ratio test. Panel Threshold regression model is superior to other model using nonlinear function [11].

The equation of the interest is given below;

$$
\mathrm{y}_{\mathrm{it}}=\beta_{1} \mathrm{x}_{\mathrm{it}} \mathrm{I}\left(\mathrm{q}_{\mathrm{it}} \leq \gamma\right)+\beta_{2} \mathrm{x}_{\mathrm{it}} \mathrm{I}\left(\mathrm{q}_{\mathrm{it}}>\gamma\right)+\mu_{\mathrm{i}}+\mathrm{e}_{\mathrm{it}}
$$

Another way of writing equation (1) is

$$
\begin{aligned}
& \mathrm{y}_{\mathrm{it}}=\beta_{1} x_{\mathrm{it}}+\mu_{\mathrm{i}}+\mathrm{e}_{\mathrm{it}} \mathrm{q}_{\mathrm{it}} \leq \gamma \\
& \mathrm{y}_{\mathrm{it}}=\beta_{2} x_{\mathrm{it}}+\mu_{\mathrm{i}}+\mathrm{e}_{\mathrm{it}} \mathrm{q}_{\mathrm{it}}>\gamma
\end{aligned}
$$

Where the data is from the balanced panel with $\left\{\mathrm{y}_{\mathrm{it}}, \mathrm{q}_{\mathrm{it}}, x_{\mathrm{it}}\right.$ : $1 \leq i \leq n, 1 \leq t \leq T\}$. The dependent variable $\mathrm{y}_{\mathrm{it}}$ is scalar, the threshold variable $\mathrm{q}_{\mathrm{it}}$ is scalar, and the explanatory variable $\mathrm{x}_{\mathrm{it}}$ is a $k$ vector. $I($.$) is the indicator function equal to 0$ or 1 . The error $e_{i t}$ is assumed to be independent and identically distributed (iid) with mean zero and finite variance.

\subsection{Estimation}

$\mathrm{q}_{\mathrm{it}}$ is the threshold parameter that dividing the observation into two regimes (assuming the single threshold model). The regimes are split by differing regression slopes, $\beta_{1}$ and $\beta_{2}$. We now need to know whether the threshold effect is statistically significant. The null hypothesis of threshold effect is represented by the linear constraint $H o=\beta_{1}$ and $\beta_{2}$. The threshold value is determined by least square estimation proposed by author and value of threshold that minimized the sum of squares residuals [11]. Likelihood ratio test is used for construction of confidence interval of $\gamma$. Estimation for slope parameter $\beta_{1}$ and $\beta_{2}$ on the sample split for estimation of $\gamma$.

\section{Results and Discussion}

The first step before data analysis is to run Hausman test. 
It gives us information regarding either fixed effect model or random effect model for the study.

\subsection{Fixed Effect v/s Random Effect Model}

Table 3. Fixed \& Random Effect Estimation.

\begin{tabular}{lll}
\hline Variables & Fixed effect & Random effect \\
\hline Debt to GDP & $0.0463887 * *(4.44)$ & -.0057366 \\
Inflation & $0.1984169(1.33)$ & 1682032 \\
Trade to GDP (\%) & $-0.0131158(-0.52)$ & 0246419 \\
Gross Saving & $0.2863841 * *(2.44)$ & 0509024 \\
Government Consumption & $-0.8039081 * * *(-4.22)$ & -.2451733 \\
Expenditure & $0.2172001 * *(2.21)$ & 1038423 \\
Total Investment $(\%)$ & 12.25 & - \\
F statistic & 8.15 & - \\
F test that all u_i $=0:$ & 0.0000 & 0.0001 \\
F(6,134) & - & 27.22 \\
Prob $>$ F & -0.9547 & 0 (assumed) \\
Wald chi2 (6) & 147 & 147 \\
Corr(u_i, X) & 7 & 7 \\
Number of observations & & \\
Number of groups & & \\
\hline
\end{tabular}

Note: $\mathrm{t}$-statistics are given in parenthesis. $* * *, * *, *$ denotes significance level at 1 percent, 5 percent \& 10 percent.

\subsection{Hausman Test}

Hausman test was conducted to select either fixed effect model or random effect model. The test is based on hypothesis as given below,

a) Null hypothesis > Errors are not correlated with regressors. Use Random effect model.

b) Alternative hypothesis $>$ Errors are correlated with regressors. Use Fixed effect model.

Table 4. Hausman Test.

Prob $>$ chi 2 0.0000

a) Null hypothesis: Random effect

b) Alternative hypothesis: Fixed effect

When Prob $>$ chi2 is less than 0.05 use fixed effect model.

Result presented in Table 4 Hausman test indicated the rejection of null hypothesis that fixed effect model is appropriate and consistent.

\subsection{Panel Threshold Regression Model}

This study implies the panel threshold regression model proposed by author to determine the number of threshold and its effect on dependent variable [11].

Result of Debt threshold and its impact on GDP per capita growth is presented as follows;

\subsubsection{Threshold Estimator in Single Threshold Model}

Table 5. Threshold Effect.

\begin{tabular}{ll}
\hline Threshold estimates & \\
\hline$\gamma$ & $62.4 \%$ \\
\hline
\end{tabular}

First of all, we find the threshold number in the model. Null hypothesis $\mathrm{H}_{0}: \beta_{1}=\beta_{2}$ (No threshold effect) and alternative hypothesis is $\mathrm{H}_{1}: \beta_{1} \neq \beta_{2}$ (threshold effect exist). The result reveals a single threshold model is $62.4 \%$ with $95 \%$ confidence interval $(58.2400 ; 62.9200)$.

\subsubsection{Threshold Significance in Single Threshold Model}

Table 6. Significance of Threshold Effect.

\begin{tabular}{lll}
\hline F statistics & p-value & Critical values (\%) \\
\hline 13.09 & 0.1833 & - \\
\hline
\end{tabular}

The significance level of single threshold model with $p$ value is 0.1833 . As a result, the null hypothesis is accepted and found linear relationship between debt and GDP growth and threshold effect does not exist.

\subsubsection{Impact of Debt on GDP Per Capita Growth (Single Threshold Model)}

Table 7. Impact of Debt on GDP Per Capita Growth.

\begin{tabular}{ll}
\hline Impact of debt on GDP Growth & \\
\hline$\beta_{1}$ & $0.07 * * *(5.33)$ \\
$\beta_{2}$ & $0.047 * * *(4.70)$ \\
\hline
\end{tabular}

\subsubsection{Explanatory Variables and GDP Per Capita Growth}

Table 8. Impact of Explanatory Variables on GDP Per capita Growth.

\begin{tabular}{ll}
\hline Impact of Explanatory variables & \\
\hline Inflation & $0.1676999(1.15)$ \\
Trade to GDP & $0.0204745(0.75)$ \\
Gross Saving & $0.2906248 * *(2.54)$ \\
Gov. Expenses & $-0.7441762 * * *(-3.98)$ \\
Total Investment $(\%)$ & $0.2590204 * * *(2.67)$ \\
\hline
\end{tabular}

F test that all $\mathrm{u} \_\mathrm{i}=0: \mathrm{F}(6,133)=7.99$ Prob $>\mathrm{F}=0.0000$

Note: t-statistics are given in parenthesis and $* * * / * * / *$ denotes the variables are statistically significant at 1 percent, 5 percent $\& 10$ percent respectively.

Table 7 indicates the estimation of regression slope in the model shows the effect of Debt in the two regimes as follows:

1. When Debt $\leq 62.4$, the coefficient value (0.07) shows the positive relationship between debt and GDP per capita growth that one percent rise in debt would result increase in GDP per capita growth by 0.07 percent.

2. When Debt $>62.4$, the coefficient value (.047) also indicates the positive relationship between debt and GDP per capita growth that one percent increase by debt leads to GDP growth appreciation by 0.047 percent.

The model suggests the current debt threshold level for selected G7 advance countries is $62.4 \%$ and beyond and above the threshold level significant positive effect on GDP growth. It shows that large stock of public debt slow down the GDP per capita growth of G7 countries in regime 1 and regime 2 .

\subsection{Explanatory Variables}

1. Inflation has positive effect on GDP per capita growth of G7 advance countries with coefficient value (0.1676999). The result does not produce significant result between the variables. The result suggested that those countries experiencing stable inflation rate have positive but insignificant impact on GDP per capita growth. 
2. Trade to GDP has also positive but insignificant effect on GDP per capita growth of G7 advance countries with coefficient value $(0.0204745)$. The finding of the study suggested that those having large export plus import to GDP have positive but insignificant impact on GDP per capita growth of G7 advance countries.

3. Gross saving to GNI has significant positive effect on GDP per capita growth of G7 advance countries. The coefficient value $(0.2906248)$ shows positive effect that 10 percent increase in gross saving causes an appreciation of $29 \%$ GDP per capita growth. The estimation result shows that high gross saving of the countries has experiencing positive effect on GDP per capita growth of advance countries.

4. Government expenditure is significant negative effect on GDP per capita growth with coefficient value $(-0.7441762)$ that one percent increase in government expenditure leads to $74 \%$ decreases in GDP per capita growth. The result suggested that those advance countries experiencing high government consumption expenditure has adverse effect on GDP per capita growth.

5. Total investment is significant positive effect on GDP per capita growth. The coefficient value $(0.2590204)$ indicates that one percent increase in total investment causes an increase in GDP per capita growth of G7 advance countries. The result is in line with previous studies that investment plays a vital role to enhance or increase in the GDP per capita growth.

\section{Conclusion}

This study investigates the relationship between public debt and GDP per capita growth of G7 countries by employing the fixed effect panel threshold regression model. In order to find a threshold level, public debt to GDP is used as a threshold variable in model. The study find the threshold level of public debt is $62.40 \%$. The estimation result indicates that public debt threshold is lower and higher than $62.4 \%$ found positive impact on GDP per capita growth. Moreover, the study provides significant relationship in both regimes and entire sample is divided into two regimes but the magnitude of public debt impact on both regimes is not similar. It reveals that public debt has significant potential impact on GDP per capita growth in regime 2 and slightly lower the impact in regime 1 due to huge debt stock.

In order to summarize the results of explanatory variables of the study such as inflation and trade to GDP found insignificant but positive relationship with GDP per capita growth while government expenditure significant negative result in the study. Gross saving and total investment exhibit a positive significant relationship with GDP per capita growth.

\section{Acknowledgements}

I acknowledged that there is no internal or external source of funding for this article.

\section{References}

[1] R. C. Okeke and A. N. Idike, "Public Debt and Sustainable National Development in Nigeria: Analysis of Fundamental Issues," International Letters of Social and Humanistic Sciences, vol. 74, pp. 41-47, 2016.

[2] M. Ismihan and F. G. Ozkanb, "Public debt and financial development: A theoretical exploration," Economics Letters, vol. 115, pp. 348-351, 2012.

[3] A. Tešić, D. Ilić and A. T. Đelic, "CONSEQUENCES OF FISCAL DEFICIT AND PUBLIC DEBT IN FINANCING THE PUBLIC SECTOR," Economics of Agriculture, vol. 61, no. 1, pp. 177-194, 2014.

[4] A. Schclarek, "Debt and Economic Growth in Developing and Industrial Countries," 2004.

[5] C. M. Reinhart and K. S. Rogoff, "Growth in a Time of Debt," American Economic Review, vol. 100, pp. 573-578, 2010.

[6] M. Lof and T. Malinen, "Does sovereign debt weaken economic growth? A panel VAR analysis," Economics Letters, vol. 112, pp. 403-407, 2014.

[7] M. S. Kumar and J. Woo, "PUBLIC DEBT AND GROWTH," 2015.

[8] M. Eberhardt and A. F. Presbitero, "Public debt and growth: Heterogeneity and non-linearity," Journal of International Economics, vol. 97, pp. 45-58, 2015.

[9] D. W. Elmendorf and N. G. Mankiw, "Government Debt," Handbook of Macroeconomics, vol. 1, no. 3, pp. 1615-1669, 1999.

[10] E. Baldacci and M. Kumar, "Fiscal Deficit, Public Debt, and Sovereign Bonds Yields," IMF Working Papers 10, p. 184, 2010.

[11] B. E. Hansen, "Threshold e!ects in non-dynamic panels: Estimation, testing, and inference," Journal of Econometrics, vol. 93, pp. 345-368, 1999. 